\title{
The nutritive value of rumen micro-organisms in ruminants
}

\section{The apparent digestibility and net utilization of microbial $\mathbf{N}$ for growing lambs}

\author{
BY E. STORM, E. R. ØRSKOV AND R. SMART \\ Rowett Research Institute, Bucksburn, Aberdeen AB2 9SB
}

(Received 12 November 1982 - Accepted 13 May 1983)

\begin{abstract}
1. Four experiments were conducted with eighteen lambs sustained entirely by intragastric nutrition at gross energy inputs varying from 430 to $860 \mathrm{~kJ} / \mathrm{kg}$ live weight ${ }^{0.75}\left(\mathrm{~W}^{0.75}\right)$. Isolated rumen micro-organisms (RMO) were infused into the abomasum in quantities varying from 0 to $2 \mathrm{~g}$ digestible $\mathrm{N} / \mathrm{kg} \mathrm{W}^{0.75}$ to assess the increase in N balance as a result of increasing RMO input when $\mathrm{N}$ was limiting.

2. The over-all utilization of N from RMO (RMO-N) could be described by the equation $y=0.543 x-0.457$, residual $\mathrm{SD}=0.037$, where $y$ is the $\mathrm{N}$ balance and $x$ is the abomasal input of RMO-N, both expressed in $\mathrm{g} / \mathrm{kg}$ $\mathrm{W}^{0} \cdot 75$. Thus the coefficient of efficiency of utilization of infused RMO-N was 0.543 (SE 0.008). The coefficient of efficiency of utilization of RMO-N truly digested (i.e. the biological value) was 0.659 (SE 0.015 ).

3. The RMO-N input (mean with SE) at $\mathrm{N}$ equilibrium was $0.843(0.009) \mathrm{g} / \mathrm{kg} \mathrm{W}^{0.75}$. The true digestibility of RMO-N was $0.813(0.004)$. The urinary $\mathrm{N}$ excretion when no $\mathrm{N}$ was infused was $0.329(0.008) \mathrm{g} / \mathrm{kg} \mathrm{W}^{0.75}$ and the $\mathrm{N}$ excreted via the faeces with zero $\mathrm{N}$ input was $0.036(0.009) \mathrm{g} / \mathrm{kg} \mathrm{W}^{0.75}$.
\end{abstract}

Under most dietary conditions the microbial protein synthesized in the forestomach of ruminant animals accounts for $60-85 \%$ of the total amino acid (AA) nitrogen (AAN) entering the small intestine (Smith, 1975; Agricultural Research Council, 1980; Ørskov, 1982). Furthermore, the AA composition of this material appears to be constant irrespective of dietary and animal conditions (Storm et al. 1983). It has been difficult to obtain precise estimates of the nutritive value of microbial $\mathrm{N}$ for ruminants due to difficulties in isolating sufficient quantities of rumen micro-organisms (RMO) for experiments with large animals, though some evaluations of nutritive value have been undertaken using rats (Johnson et al. 1944; McNaught et al. 1954; Mason \& Palmer, 1971).

Large-scale isolation of rumen micro-organisms was described in an earlier paper in this series (Storm \& Ørskov, 1983). The present paper describes the results of four experiments in which RMO were infused abomasally in sheep otherwise maintained by intraruminal infusion of volatile fatty acids (VFA) and minerals (Ørskov et al. 1979). Using this method, the quantities of RMO and energy infused could be estimated accurately and varied independently of each other. A preliminary account of some of this work has already been published (Storm \& Ørskov, 1982).

\section{MATERIALS AND METHODS}

\section{Animals}

Four female and fourteen castrated male Suffolk $\times$ (Finnish Landrace $\times$ Dorset Horn) lambs were used. They were fitted with rumen cannulas and abomasal catheters, as described by Ørskov et al. (1979). Intragastric nutrition was started 2-3 weeks after surgery.

\section{Infusates and infusion procedure}

The VFA mixture consisted of acetic, propionic and butyric acids in molar proportions of $0.65,0.25$ and 0.10 respectively, together with the major minerals and water (Ørskov et al. 1979). The VFA infusates were infused continuously at the rate of $2500 \mathrm{ml} / \mathrm{d}$ using a metering pump (Metering Pump Ltd, London). A buffering solution was also infused at 
the rate of $2500 \mathrm{ml} / \mathrm{d}$ to maintain a rumen $\mathrm{pH}$ between 6.2 and 6.7 , as previously described (Ørskov et al. 1979). Freeze-dried micro-organisms isolated from whole rumen contents (Storm \& Ørskov, 1983) were reconstituted in $2500 \mathrm{ml}$ water daily and infused abomasally together with trace minerals and vitamins. The vessels holding the reconstituted microbial infusate were kept at $0^{\circ}$. The full chemical composition of the microbial material used in the present study has been given previously (Storm \& Ørskov, 1983). The $\mathrm{N}$ content of the freeze-dried material was $97 \mathrm{~g} / \mathrm{kg}$.

\section{Management}

Lambs were gradually introduced to the infusion procedure over a 2-week period, after which feed was removed and the experiment begun. The lambs were weighed at weekly intervals during the infusion period so that their nutrient allowance could be calculated on the basis of their metabolic live weight $\left(\mathrm{kg} \mathrm{W}^{0.75}\right)$.

\section{Expt 1}

Four lambs were used, all of which were infused with VFA to supply $430 \mathrm{~kJ} / \mathrm{kg} \mathrm{W}^{0.75}$ per d. RMO was given to provide, in sequence, $1 \cdot 67,1 \cdot 34,1 \cdot 00,0 \cdot 67,0 \cdot 33,0 \cdot 67,1.00,1 \cdot 34$, 1.67 and $0 \mathrm{~g}$ RMO-N/ $/ \mathrm{kg} \mathrm{W}^{0.75}$ per d (for two lambs), or $0.33,0.67,1.00,1.34,1.67,1.34$, $1.00,0.67,0.33$ and $0 \mathrm{~g}$ RMO-N $/ \mathrm{kg} \mathrm{W}^{0.75}$ per $\mathrm{d}$. Each level of RMO-N was infused for a period of $3 \mathrm{~d}$. The $\mathrm{N}$-free period (when no RMO-N was given) was of $7 \mathrm{~d}$ duration. Faeces were collected and bulked for the whole experiment. The urine was collected and analysed daily.

\section{Expt 2}

Four lambs were used. The VFA input was adjusted to give $860 \mathrm{~kJ} / \mathrm{kg} \mathrm{W}^{0 \cdot 75}$ daily. RMO was given to provide in sequence $0 \cdot 67,1 \cdot 34,2 \cdot 002 \cdot 67,2 \cdot 00,1 \cdot 33,1 \cdot 00,0 \cdot 33$ and $0 \mathrm{RMO}-\mathrm{N} / \mathrm{kg}$

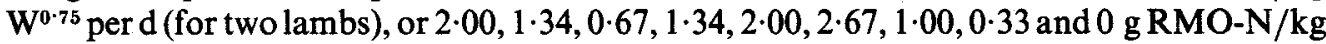
$\mathrm{W}^{0.75}$ per d. Polyethylene glycol 4000 (PEG) was included in the abomasal infusate at a rate of $10 \mathrm{~g} / \mathrm{kg}$ freeze-dried RMO. Each level of infusion was maintained for at least $4 \mathrm{~d}$. The $\mathrm{N}$-free period was $7 \mathrm{~d}$. Urine was collected and analysed daily for $\mathrm{N}$. The faeces were collected daily and bulked for the whole experiment. However, on the last day of each period a sample of faeces was taken and analysed for PEG (Smith, 1958) and N.

\section{Expts 3 and 4}

Although the main objective of Expts 3 and 4 was to estimate the limiting AA of microbial protein for ruminants by supplementing a basal level of RMO with various pure L-AA mixtures (E. Storm and E. R. Ørskov, unpublished results), the $\mathrm{N}$ balance results obtained in periods when no AA supplements were given (1.67 and $0.93 \mathrm{RMO}-\mathrm{N} / \mathrm{kg} \mathrm{w}^{0.75}$ per d) are reported here. The rumen VFA infusion in Expt 4 was adjusted to maintain an energy supply of $750 \mathrm{~kJ} / \mathrm{kg} \mathrm{W}^{0.75}$ per d from VFA. PEG was included at a rate of $10 \mathrm{~g} / \mathrm{kg}$ freeze-dried RMO. Eleven wether lambs were used, all of which received the two treatments described previously. Each level of microbial protein input was maintained for a period of $3 \mathrm{~d}$. Urine was collected and analysed daily for N. Faeces were collected daily and bulked over the whole experiment. On the last day of each period a faecal sample was taken and analysed for PEG (Smith, 1958) and N.

\section{RESULTS}

\section{Health of the animals}

Blood samples obtained during the four experiments were analysed for erythrocytes, packed-cell volume, haemoglobin, white blood cells, sodium, potasium, calcium, magnesium, phosphorus and reducing sugars. All were found to be within the normal range (Rushton, 
Utilization of rumen micro-organisms

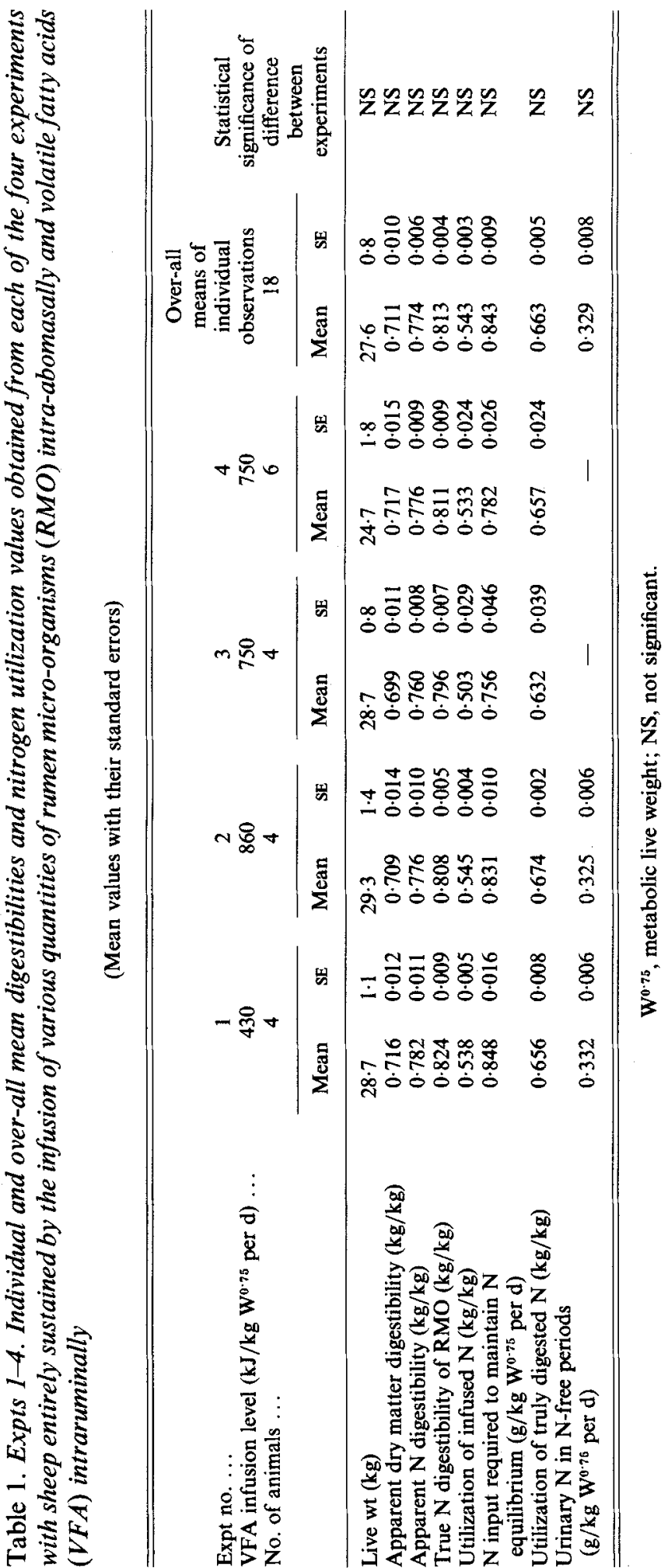


1981). One lamb in Expt 2 died due to blockage of the tube supplying the buffer solution, and was replaced by another of similar breed and weight. Post-mortem examination of the lambs at the end of each experiment showed normal rumen and abomasal development. The lining of the small intestine and of other gut tissues was similar to that usually found in animals given high-quality forages (B. F. Fell, personal communication).

\section{Expt 1}

Mean apparent digestibilities of dry matter and $\mathbf{N}$ for each animal are given in Table 1 . Since PEG was not included in the infusate and the faeces were bulked over the whole experiment, an estimate of true digestibility could not be obtained directly. Instead, the true digestibility of RMO-N was calculated using the mean estimate of endogenous faecal N (EFN) of $36 \mathrm{mg} / \mathrm{kg} \mathrm{W}^{0 \cdot 75}$, obtained in Expts 2,3 and 4. The mean represented the weighted mean from the three experiments. Using fourteen animals the SE was $9 \mathrm{mg}$. This estimated EFN was also used to calculate the mean utilization both of the total RMO-N infused, the truly digested RMO-N, and the amount required to achieve $\mathrm{N}$ equilibrium. The amount of urinary $\mathrm{N}$ excreted during the $\mathrm{N}$-free period is also given in Table 1.

\section{Expts 2, 3 and 4}

The mean results obtained in Expts 2, 3 and 4 are given in Table 1. Although individual estimates of endogenous faecal $\mathbf{N}$ were derived by extrapolation to zero intake in each animal, the mean value obtained from Expts 2,3 and 4 of $36 \mathrm{mg} \mathrm{N} / \mathrm{kg} \mathrm{W}^{0.75}$ has been used to calculate the true RMO-N digestibility and RMO-N utlization for all animals used in these experiments. The urinary $\mathrm{N}$ excretion at zero $\mathrm{N}$ intake was determined in all lambs used in Expts 1 and 2 only. The net utilization of infused $\mathrm{N}$ and the efficiency of utilization of truly-digested RMO-N are calculated. A summary of the four experiments is given in Table 1 , together with the standard error of the four mean values. None of the values were significantly different from the mean of the four experiments.

There was a highly-significant linear relationship between RMO-N input and $\mathrm{N}$ balance in each lamb over all periods except for Expt 1 at RMO-N inputs higher than $1.05 \mathrm{~g} / \mathrm{kg}$ $\mathrm{W}^{0.75}$. These are presented in Fig. 1. Excluding values higher than $1.05 \mathrm{~g} \mathrm{RMO}-\mathrm{N} / \mathrm{kg} \mathrm{W}^{0.75}$ for Expt 1, all the values from all the individual animals could be combined and described by one equation: $y=0.543 x-0.457$, where $x$ is RMO-N infused and $y$ is the $\mathrm{N}$ balance, both expressed as $\mathrm{g} / \mathrm{kg} \mathrm{W}^{0.75}$. The residual standard deviation (RSD) was 0.037 . The slope (coefficient) defines the proportion of RMO-N which is utilized or the net $\mathrm{N}$ utilization (NNU). The mean NNU of RMO-N for all treatments was therefore 0.543 . The standard error of the regression coefficient was 0.008 . The mean values for the efficiency of utilization of truly-digested RMO-N (hereafter referred to as the biological value $\left(\mathrm{BV}_{\mathrm{N}}\right)$ of RMO-N) was 0.659 (SE 0.015). The over-all mean intake of RMO-N required to maintain $\mathrm{N}$ balance was 0.801 (SE 0.0024 ) g RMO-N/ $\mathrm{kg} \mathrm{W}^{0.75}$. The intercept value of 0.457 for the $\mathrm{N}$ loss when no $\mathrm{N}$ was infused was higher than the total endogenous $\mathrm{N}$ loss calculated as the urinary $\mathrm{N}$ with $\mathrm{N}$-free infusion plus the EFN $\left(329+36=365 \mathrm{mg} \mathrm{N} / \mathrm{kg} \mathrm{W}^{0.75}\right)$.

\section{DISCUSSION}

\section{Animal health and performance}

The loss of an animal in Expt 2 was due to acidosis, precipitated by blockage of the buffer supply. Otherwise the animals remained in good health throughout the experiment and appeared normal as judged by all the haematological and biochemical blood indices measured.

Although the rumen wall always appears normal in animals maintained by intragastric nutrition, some atrophy of the small and large intestinal walls is often found in lambs kept 


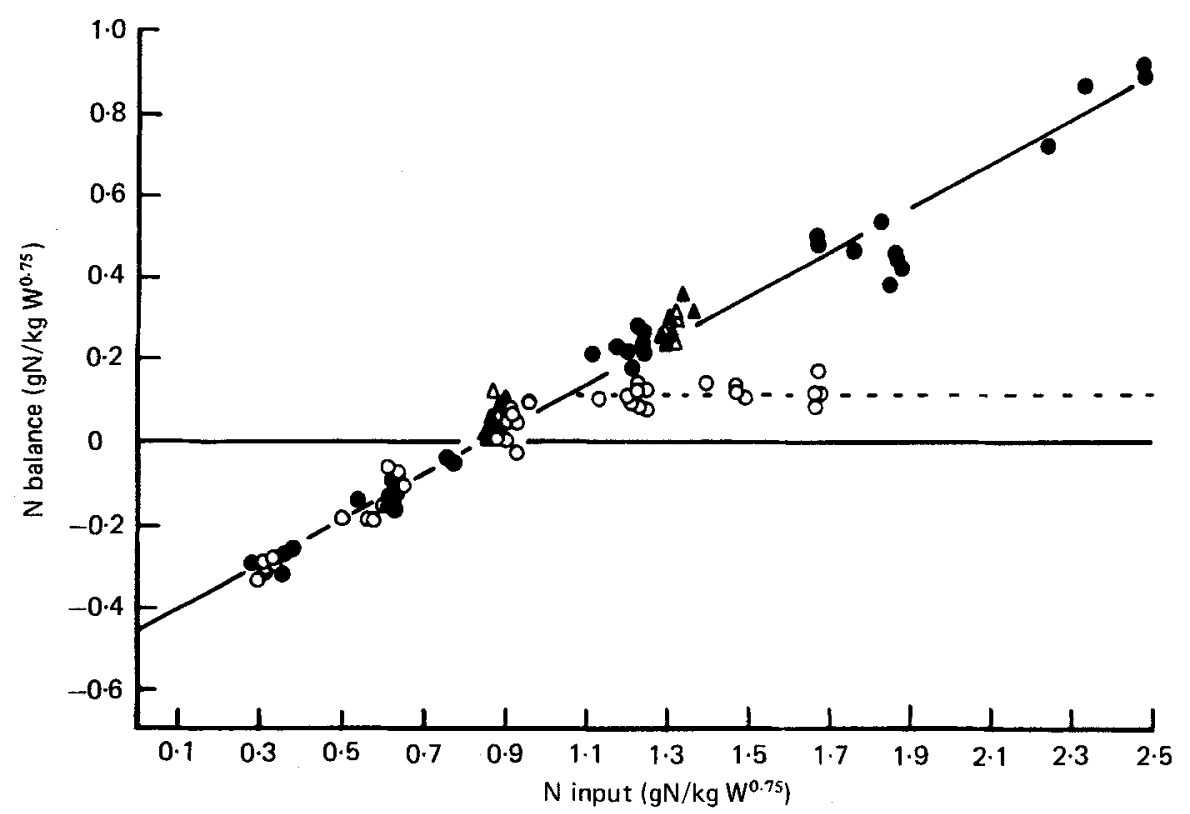

Fig. 1. The relationship between $\mathrm{N}$ input in RMO (g N/kg live weight ( $\left.\mathrm{W}^{0 \cdot 75}\right)$ ) and $\mathrm{N}$ balance $\left(\mathrm{g} \mathrm{N} / \mathrm{kg} \mathrm{W}^{\circ} \cdot 75\right)$ in eighteen lambs. The gross energy infused was $430 \mathrm{~kJ}(\mathrm{O})$ Expt $1,860 \mathrm{~kJ}(\mathrm{O})$ Expt 2 , and $750 \mathrm{~kJ}(\triangle \Delta)$ Expts 3 and 4.

under the infusion regimen for long periods of time, using casein as the only protein source. However, the histological examination of the rumen and intestinal walls of the lambs used in this study, which were abomasally infused with RMO as the only $\mathrm{N}$ source, showed no atrophy and appeared essentially identical to those found in ruminants receiving high-quality forage diets (B.F. Fell, personal communication).

When given sufficient energy (Expts 2,3 and 4) the animals were capable of an average growth rate of approximately $100 \mathrm{~g} / \mathrm{d}$. Furthermore, post-mortem examination showed the carcasses of the animals to be visually similar to those of animals given normal diets (W. Corrigall, personal communication).

\section{Efficiency of utilization of truly-absorbed $N\left(B V_{N}\right)$}

For the truly-utilized proportion of the RMO-N input to be expressed relative to that truly-absorbed, an estimate of the true digestibility of RMO-N is needed. Any fermentation in the large intestine (Mason \& White, 1971) will introduce the possibility of an exchange of $\mathbf{N}$ between the endogenous and truly-digested dietary $\mathbf{N}$ fractions and, hence, an error in the estimation of true digestibility.

In a subsequent paper in this series (Storm et al. 1983) using similar RMO preparations and infusion procedures, with the animals equipped with ileal cannulas, a true $\mathrm{N}$ digestibility and endogenous $\mathrm{N}$ loss in the small intestine of $0.815 \mathrm{~kg} / \mathrm{kg}$ and $39 \mathrm{mg} / \mathrm{kg} \mathrm{W}$ W $^{0.75}$ were found. These values are very similar to the respective values here of $0.813 \mathrm{~kg} / \mathrm{kg}$ and $36 \mathrm{mg} \mathrm{N} / \mathrm{kg}$ $\mathrm{W}^{\mathbf{0} 75}$ for the whole gut. The similarity between the values obtained over the small intestine and over the whole digestive tract indicated that, under the experimental conditions used, the net $\mathrm{N}$ exchange across the hind-gut wall was negligible. 
Table 2. Published values of true nitrogen digestibility, biological value and net $N$ utilization of mixed rumen micro-organisms (RMO)

\begin{tabular}{|c|c|c|c|c|}
\hline Source & Method used & $\begin{array}{c}\text { True N } \\
\text { digestibility }\end{array}$ & $\begin{array}{l}\text { Biological } \\
\text { value }\end{array}$ & $\begin{array}{c}\text { Net } \mathrm{N} \\
\text { utilization }\end{array}$ \\
\hline $\left.\begin{array}{l}\text { Harris \& Mitchell (1941) } \\
\text { Johnson } \text { et al. }(1944)\end{array}\right\}$ & $\begin{array}{l}\text { Sheep given purified diets } \\
\text { with urea as the main source }\end{array}$ & $\begin{array}{l}0.89 \\
0.55\end{array}$ & $\begin{array}{l}0.62 \\
0.66\end{array}$ & $\begin{array}{l}0.55 \\
0.36\end{array}$ \\
\hline $\left.\begin{array}{l}\text { Reed et al. (1949) } \\
\text { McNaught } \text { et al. }(1950) \\
\text { McNaught et al. }(1954) \\
\text { Bergen et al. }(1968) \\
\text { Mason \& Palmer (1971) }\end{array}\right\}$ & $\begin{array}{l}\text { Rats given semi-purified } \\
\text { diets with isolated RMO as } \\
\text { the main source of protein }\end{array}$ & $\begin{array}{l}0.64 \\
0.73 \\
0.74 \\
0.75 \\
0.79\end{array}$ & $\begin{array}{l}0.79 \\
0.88 \\
0.81 \\
0.85 \\
0.72\end{array}$ & $\begin{array}{l}0.51 \\
0.64 \\
0.60 \\
0.64 \\
0.57\end{array}$ \\
\hline Present work & $\begin{array}{l}\text { Intragastric infusion of RMO } \\
\text { in eighteen sheep }\end{array}$ & 0.81 & 0.67 & 0.54 \\
\hline
\end{tabular}

\section{Transformation of $B V$ estimates}

Due to the uncertain nature of the endogenous faecal $\mathrm{N}$ and the difficulty of estimating it, the few available $\mathrm{BV}_{\mathrm{N}}$ estimates of RMO-N in ruminants have previously been based on apparent rather than on true digestibility estimates (Harris \& Mitchell, 1941; Johnson et al. 1944; Bird, 1972). Therefore, before the estimates of true $N$ digestibility and $\mathrm{BV}_{\mathrm{N}}$ of RMO obtained in this study are compared with those found in the literature, many of which are obtained with single-stomached animals, it may be useful to consider the relationship between the true and the apparent values for the $\mathrm{N}$ digestibility and $\mathrm{BV}_{\mathrm{N}}$ as they apply to single-stomached animals and to ruminant animals without an active rumen fermentation.

The $\mathrm{BV}_{\mathrm{N}}$, whether derived from apparent or from true $\mathrm{N}$ digestibility, is based on an estimate of the urinary $\mathbf{N}$ from which the constant endogenous urinary $\mathbf{N}$ loss has been subtracted. However, only in the calculation of the true $B_{N}$ has the endogenous faecal $\mathrm{N}$ loss also been considered. Theoretically, therefore, it is true $\mathrm{BV}_{\mathrm{N}}$ that most accurately describes the true value of the digested $\mathrm{N}$ supply to the host animal.

Since the true $\mathrm{N}$ digestibility must logically be numerically higher than the apparent $\mathrm{N}$ digestibility, it follows that the change in urinary $\mathbf{N}$ output measured, when a change in $\mathrm{N}$ input is imposed on the animal, will form a smaller proportion of the truly-absorbed $\mathrm{N}$ fraction than it does of the apparently-absorbed fraction. Hence a $\mathrm{BV}_{\mathrm{N}}$ estimate based on the true $\mathbf{N}$ digestibility will be higher than one based on the apparent $\mathrm{N}$ digestibility. The $\mathrm{BV}_{\mathrm{N}}$ obtained using apparent digestibility can be transformed to the true $\mathrm{BV}_{\mathrm{N}}$ using the expression:

$$
\text { True } \mathrm{BV}_{\mathrm{N}}=1-\left\{\frac{\text { Apparent digestibility of } \mathrm{N}\left(1-\text { apparent } \mathrm{BV}_{\mathrm{N}}\right)}{\text { True digestibility of } \mathrm{N}}\right\}
$$

(derived by Storm, 1982).

\section{Previous investigations}

A summary of the results of a number of experiments designed to investigate the nutritional value of RMO is given in Table 2. The results have been arranged according to the experimental method and class of micro-organisms involved. In the following section the individual methods used by the workers will be briefly discussed and the general findings compared with the estimates obtained in this study.

Semi-purified urea diets. In one of the earliest attempts to investigate the nutritive value of RMO to ruminants, Harris \& Mitchell (1941) conducted a N balance trial using sheep 
given a semi-purified diet at various intakes of $\mathrm{N}$. A difficulty of this approach is the uncertainty of the amounts of microbial biomass synthesized and subsequently leaving the rumen. Perhaps the most important shortcoming of using fed ruminants to investigate the nutritional value of RMO, is the extent of recycling and rumen microbial reutilization of waste $\mathrm{N}$ from tissue metabolism and hind-gut digestion. The extent of this recyling will depend upon whether the requirements of the micro-organisms are satisfied by dietary (exogenous) $\mathrm{N}$. Hence estimates of the utilized fraction of the absorbed $\mathrm{BV}_{\mathrm{N}}$ and true $\mathrm{N}$ digestibility, when obtained from functioning ruminants, will always be confounded by the variable opportunities within the individual animal for its RMO to utilize recycled N.

\section{Non-ruminant in vivo methods}

Several workers have attempted to overcome the difficulties involved with the use of ruminants by using rats (Table 2), the assumption being that RMO-N has the same nutritive value for ruminants as for rats. Apart from possible differences in the digestive and absorptive abilities of single-stomached animals and ruminants (Barnard, 1969; Dobson et al. 1979), there may also be differences in the efficiency of utilization of both absorbed amino and nucleic acids (Peers, 1977; Razzaque et al. 1981). Furthermore, ruminants absorb VFA as their main source of energy and may need to use amino acids for gluconeogenesis. Nevertheless, $\mathbf{N}$ balance procedures for rats are generally highly standardized and reproducible and (perhaps most important) require only small quantities of test material.

The very high levels of lysosyme and RNA found in ruminants' gastric and small intestinal digesta (Dobson et al. 1979) may help to explain why the over-all true digestibility of RMO-N obtained with ruminants in this study was somewhat higher than those reported for rats. However, the results with rats are variable and this may reflect differences in experimental methods used, such as the method of drying, e.g. freeze-drying (Mason \& Palmer, 1971), extraction with alcohol and drying at $38^{\circ}$ (McNaught et al. 1954). Alternatively there may be real differences in digestibility between microbial preparations with different dominant microbial species (Bergen et al. 1968).

Estimates of the $\mathrm{BV}_{\mathrm{N}}$ of RMO obtained with rats have also been variable (see Table 2). Some of this variability may be accounted for by differences in the level of protein in the test diets (Johnson et al. 1944) or in the type and age of rats used (McNaught et al 1954). Nevertheless, estimates for the $\mathrm{BV}_{\mathrm{N}}$ of $\mathrm{RMO}$ obtained with rats are generally higher than our estimates. A possible reason for the discrepancy may be an active hind-gut fermentation (Mason \& Palmer, 1971) as outlined previously. It is interesting to note that the estimates of $\mathrm{N}$ digestibility and $\mathrm{BV}_{\mathrm{N}}$ obtained by Mason \& Palmer (1971), who conducted the largest and most comprehensive of the rat experiments published, are in best agreement with our values obtained with ruminants.

When the methods used are taken into consideration, previously-published estimates largely support the findings obtained in Expts 1, 2, 3 and 4 presented here, namely that the over-all efficiency of utilization of the total $\mathrm{N}$ fraction of RMO is 0.54 . The true $\mathrm{N}$ digestibility of RMO-N in the whole animal is 0.81 , and absorbed RMO-N is utilized with an efficiency of approximately 0.67 .

\section{REFERENCES}

Agricultural Research Council (1980). The Nutrient Requirements of Ruminant Livestock. Slough, Bucks: Commonwealth Agricultural Bureaux.

Barnard, E. A. (1969). Nature 221, 340-344.

Bergen, W. G., Purser, D. B. \& Cline, J. H. (1968). Journal of Animal Science 27, 1497-1501.

Bird, P. R. (1972). Australian Journal of Biological Sciences 25, 185-193, 195-203.

Dobson, D. E., Dayan, E. \& Wilson, A. C. (1979). Federation Proceedings 38, 674.

Harris, L. E. \& Mitchell, H. H. (1941). Journal of Nutrition 22, 167-182. 
Johnson, B. C., Hamilton, T. S., Robinson, W. B. \& Ganey, J. C. (1944). Journal of Animal Science 3; $287-298$.

McNaught, M. L., Owen, E. C., Henry, K. M. \& Kon, S. K. (1954). Biochemical Journal 56, 151-156.

McNaught, M. L., Smith, J. A. B., Henry, K. M. \& Kon, S. K. (1950). Biochemical Journal 46, 32-36.

Mason, V. C. \& Palmer, R. (1971). Journal of Agricultural Science, Cambridge 76, 567-572.

Mason, V. C. \& White, F. (1971). Journal of Agricultural Science, Cambridge 77, 91-98.

Ørskov, E. R. (1982). Protein Nutrition in Ruminants. London and New York: Academic Press.

Ørskov, E. R., Grubb, D. A., Wenham, G. \& Corrigall, W. (1979). British Journal of Nutrition 41, $553-558$.

Peers, D. G. (1977). Proceedings of the Nutrition Society 36, 63A.

Razzaque, M. H., Topps, J. H., Kay, R. N. B. \& Brockway, J. M. (1981). British Journal of Nutrition 45, $517-527$.

Reed, F. M., Moir, R. Y. \& Underwood, E. Y. (1949). Australian Journal of Scientific Research B2, $304-317$.

Rushton, B. (1981). Veterinary Laboratory Data. London: British Veterinary Association.

Smith, R. H. (1958). Nature 182, 260-261.

Smith, R. H. (1975). In Digestion and Metabolism in the Ruminant. Proceedings of the IV International Symposium on Ruminant Physiology, pp. 399-415. Armidale, Australia: New England University Press.

Storm, E. (1982). Isolation and nutritive value of rumen micro-organisms and their limiting amino acids for growing sheep. PhD Thesis, Aberdeen University.

Storm, E., Brown, D. S. \& Ørskov, E. R. (1983). British Journal of Nutrition 50, 479-485.

Storm, E. \& Grskov, E. R. (1982). Proceedings of the Nutrition Society 41, 78A.

Storm, E. \& Ørskov, E. R. (1983). British Journal of Nutrition 50, 463-470. 